\title{
EDITORS' MESSAGE
}

\author{
Clifford I. Voss, Editor \\ William E. Wilson, Technical Editor
}

Thanks! -- The Editor and Technical Editor have now completed their first full year as producers of Hydrogeology Journal. We quickly realized how critical is the support of many others in creating four high-quality issues a year, and we would like to take this opportunity to thank those who have contributed so effectively. The authors, of course, are the backbone of the journal; the ongoing submittal of interesting, varied, and high-quality articles from authors all over the world is much appreciated. Members of the Editorial Board (see inside of front cover) have been extremely helpful in soliciting articles, conducting reviews, and lining up reviewers. David Banks has conducted and arranged for "re-Englishing" of articles that have severe language problems; by offering this service, we encourage hydrogeologists worldwide, even if they are not highly fluent in English, to submit articles to the journal. Because of the skillful translating services of Michel Bakalowicz, Xavier Sanchez-Vila, and Geneviève Ségol, we are able to publish abstracts in French and Spanish as well as English. We appreciate the comments of David Banks and Philip LaMoreaux, who each wrote an "Editor's Message" in 1995. This issue is the first of several planned theme issues, and we thank David Lerner, Guest Editor, for organizing it.

We are particularly grateful to the many colleagues who provided reviews of articles. These volunteers contribute significantly (and often anonymously) to the technical soundness of the journal. Below are listed reviewers who completed article reviews in 1995; if you would like to participate as a reviewer in 1996, please contact Clifford Voss, Editor.

Ian Acworth

William Alley

J.L. Azuara Zumaya

E. Scott Bair

David Banks

Chris Barber

Mike Barrett

Thomas J. Burbey

Joel Carillo-Rivera

Steven Carle

Richard L. Cooley

Malcolm Cox

Emilio Custodio

John B. Czarnecki

Paul Domski

Richard Allen Downing

Alan R. Dutton

Raphael Fernandez-Rubio

Andrew Fisher

Stephen Foster

Emil O. Frind

Roger Gonzales Herrera

Earl A. Greene

Thomas Grischek

C.P. Gupta

Gunnar Gustafson

F.P. Haeni

Michael Hauck

Susan Hovorka
Ken Howard
Dwight T. Hoxie
Per-Olaf Johansson
Richard Johnston
Jeremy Joseph
Kenzi Karasaki
Kenneth Kipp
Antanas A. Klimas
Leonard F. Konikow
James LaBaugh
Luc Lebbe
Ki Ha Lee
Shrikant Limaye
E.P. Löhnert
C. Lomnitz
Robert E. Mace
Jean Margat
John Mather
Mark McBride
David McCann
J. Kevin Meadows
Carl Mendoza
Shrikanta Mishra
Brian Morris
Chris Neuzil
Rune Nordqvist
S. Saleh Nour

\author{
Brennon Orr \\ Claus Otto \\ Darryll T. Pederson \\ Zell E. Peterman \\ Neil Plummer \\ David W. Pollack \\ Mike Price \\ Carl Renshaw \\ Alphonso Rivera \\ Nick Robins \\ Andrzej Rózkowski \\ Ward E. Sanford \\ Paul R. Seaber \\ Allen Shapiro \\ M. Stibits \\ Wolfgang V. Swarzenski \\ John Tellam \\ Roger Thunvik \\ Sven Tirén \\ Chin Fu Tsang \\ Kristine Uhlman \\ Mark K. Underwood \\ Genrich S. Vartanyan \\ Stratis Vomvoris \\ Geoff Williams \\ Thomas Winter \\ S. Witczak \\ Alan Wright
}

